

\section{Sumário}

A DISCRIMINAÇÃo RACIAL NO BRASIL E A ASCENSÃo DO POVO NEGRO: UM OLHAR A PARTIR DOS PRINCÍPIOS CONSTITUCIONAIS NA LUTA PELA CIDADANIA INCLUSIVA

Bruno Mello Correa de Barros e Rita Mara Albrecht

As MULHERES NO CONTEXTO DA SOCIEDADE DE CLASSES E SUA PARTICIPAÇÃO POLÍTICA NO PROCESSO LEGISLATIVO E EXECUTIVO DO BRASIL: RESTRIÇÕES E DESAFIOS

Rafael Bueno da Rosa Moreira e Marli Marlene Morais da Costa

FACTORES ASOCIADOS A LA VIOLENCIA DE GÉNERo EN PAREJAS ADOLESCENTES

Maria del Carmen Monreal Gimeno

Os IMPACTOS DAS TECNOLOGIAS DA INFORMAÇÃO NO FLUXO DE PESSOAS: VIOLAÇÕES DA LIBERDADE EM UM MUNDO SECURITIZADO

Elias Jacob de Menezes Neto, Jose Luis Bolzan de Morais e Victoria Layze Silva Fausto

El DELITO DE ENALTECIMIENTO TERRORISTA. ¿INSTRUMENTO DE LUCHA CONTRA EL PELIGROSO DISCURSO DEL ODIO TERRORISTA O MECANISMO REPRESOR DE REPUDIABLES MENSAJES DE RAPEROS, TWITTEROS Y TITIRITEROS?

Alfonso Galán Muñoz

As POLÍtiCAS PÚBLICAS E A PROMOÇão DA DIGNIDADE: UMA ABORDAGEM NORTEADA PELAS CApacidades (CAPABIlities APproach) propostas por Martha Nussbaum

Anna Paula Bagetti Zeifert e Janaína Machado Sturza

A INFLUÊNCIA DA MÍdia PARA O CONSUMO DE TABACO

Luís Renato Vedovato e Maria Carolina Gervásio Angelini

¿SON PARTE DEL BLOQUE DE CONSTITUCIONALIDAD LOS PRINCIPALES TRATADOS internacionales de derechos humanos de la ONU en Chile? Del texto positivo a la APLICACIÓN EN TRIBUNALES DE JUSTICIA Juan Pablo Díaz Fuenzalida

Potestad calificadora del Conservador de Bienes Raíces y Procedimiento Registral ....173 Sebastián Bozzo Hauri e Gonzalo Ruz Lartiga

DESARTICULAÇÃo INTERFEDERATIVA E CONCESSÃo DOS BENEFÍCIOS DE PRESTAÇÃo CONTINUADA (BPC) 
Aprendizagem Profissional e o poder público municipal: proposta de maior eficácia À POLÍTICA PÚBLICA

José Rodrigo Paprotzki Veloso

Direito A Conciliação Entre Trabalho E Família................................................229

Edilton Meireles de Oliveira Santos

Trabajo y diversidad funcional. La situación EN EL ORdenamiento JuRídico español 245 María Esther Carrizosa Prieto

Custos de TransaÇão como uma METAPolítica pública .........................................2276

João Luis Nogueira Matias e Ricardo José Brito Bastos Aguiar de Arruda

REVISITANDO O CONCEITO DE SERVIÇO PÚBLICO

Andre Luiz Dos Santos Nakamura

O Brasil FACE AOS NOVOS PADRÕES DE COMÉRCIO E INVESTIMENTO DOS ACORDOS INTERNACIONAIS

Michelle Sanchez Badin, Fabio Costa Morosini e David M. Trubek

Os contratos comerciais na Declaração dos Direitos de Liberdade Econômica (MP 881/19).

André Lipp Pinto Basto Lupi

O MARCO LEGAL DA INOVAÇÃO E O AUMENTO DA INTERAÇÃO ENTRE UNIVERSIDADE E EMPRESA: CONTRIBUIÇÕES PARA A CONSOLIDAÇÃO DO DIREITO FUNDAMENTAL AO DESENVOLVIMENTO ....352 Thiago Paluma e Eline Débora Teixeira

RELICITAÇÃo DAS CONCESSÕES DE GERAÇÃo DE ENERGIA ELÉTRICA E A REVERSÃo DE BENS....372 Patrícia Regina Pinheiro Sampaio e Sergio Guerra

FinANCIAMENTO TRANSGERACIONAL DA INFRAESTRUTURA VERDE FLORESTAL: O SISTEMA DE PAGAMENTO POR SERVIÇOS AMBIENTAIS COMO INSTRUMENTO DE GESTÃO DE RISCOS NA SOCIEDADE CONTEMPORÂNEA...................................................................................................390

Délton Winter de Carvalho e Kelly de Souza Barbosa

Mediação como Política Pública para Tratamento de Conflitos Consumeristas ..... 415 Fernanda Sartor Meinero e Fernando Pedro Meinero

A ParticipaÇão do AMICUS CURIAE EM DECISÕES JUdiCIAIS E SUA CONSEQUENTE CONTRIBUiÇÃo para efetivação de Políticas Públicas .429

Viviane Nobre Santana 
A ISONOMIA TRIBUTÁRIA COMO LIMITE À TRIBUTAÇÃo E À CONCESSÃO DE ISENÇÕES FISCAIS, E A INEFETIVIDADE DO CONTROLE JURISDICIONAL DESSAS ISENÇÕES..................................450

Paulo Alves da Silva Paiva e Alexandre Augusto Batista de Lima

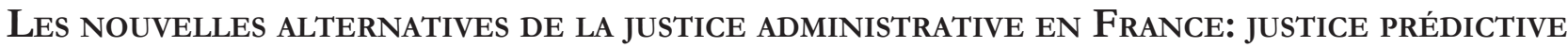
ET JUSTICE AMIABLE

Marie-Odile Diemer

O ESTADO DA LUXÚRIA: A PARÁBOLA DO BMW E A REAL DIMENSÃo DO DEBATE SOBRE A RESERVA DO POSSÍVEL: ESCASSEZ DE RECURSOS OU ORDENAÇÃo DE PRIORIDADES?................................484 Assis José Couto do Nascimento

O PODER CONSTITUINTE

José Levi Mello do Amaral Júnior

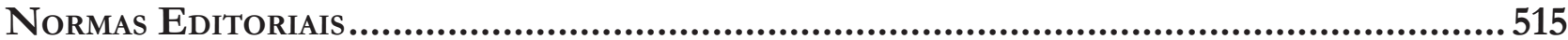

Envio dos trabalhos: 


\title{
A discriminação racial no Brasil e a ascensão do povo negro: um olhar a partir dos princípios constitucionais na luta pela cidadania inclusiva*
}

\author{
Racial discrimination in Brazil and the \\ ascension of the black people: a look at the \\ constitutional principles in the fight of inclusive \\ citizenship
}

Bruno Mello Correa de Barros**

Rita Mara Albrecht***

\section{Resumo}

O presente trabalho tem como escopo de desenvolvimento promover uma análise crítico-reflexiva acerca do povo negro e sua luta pela cidadania inclusiva. Nesse sentido, quer, objetivamente, verificar os instrumentos e princípios constitucionais que balizam tal circunstância, de modo que tal nicho social tenha acesso pleno a todos os bens jurídicos tutelados pelo ordenamento, tais como educação, saúde, transporte e outros direitos fundamentais. Sendo assim, o artigo encontra-se dividido a partir de três eixos temáticos, sendo o primeiro destinado a tratar da discriminação racial sob o ponto de vista histórico e cultural, já o segundo eixo destina-se a traçar um olhar sobre a ascensão, desenvolvimento e transformação social do povo negro na contemporaneidade. Por fim, o último eixo tem como pressuposto verificar os princípios constitucionais que balizam uma cidadania inclusiva, com base na observação da ADPF n 186 . Para a feitura do presente trabalho, utilizou-se, em sede de aporte metodológico, o método de abordagem hipotético-dedutivo, calcado nas premissas constitucionais, bem como método de abordagem histórico e funcionalista. Corroborando tais métodos, implementou-se a utilização da técnica de pesquisa baseada em fonte documental e pesquisa bibliográfica. Em sede de resultados preliminares, verifica-se o pleno entendimento da utilização relevante das ações afirmativas, argumentação jurídica potencialmente extraída da ADPF no 186, RE $\mathrm{n}^{\circ} 597.285 / \mathrm{RS}$ e $\mathrm{ADC} \mathrm{n}^{\circ} 41$, as quais propõem a questão relativa de plena eficácia de tais instrumentos como balizadores de uma inclusão cidadã com base nas balizas constitucionais e direitos fundamentais.

Palavras-chave: Ascensão. Cidadania inclusiva. Desenvolvimento. Negros. Princípios constitucionais.

** Mestre em Direito pelo PPGD da Universidade Federal de Santa Maria - UFSM. Coordenador do Curso de Ciências Contábeis da Faculdade Metodista Centenário - FMC. Docente do Curso de Direito da FMC e Coordenador dos Trabalhos de Conclusão de Curso - TCC do Curso de Direito da FMC. E-mail: brunomellocbarros@gmail.com ou bruno.barros@fames.metodista.br

*** Acadêmica do Curso de Direito da Faculdade Metodista Centenário - FMC. E-mail: Albrecht.e.rita@gmail.com 


\section{Abstract}

The present work has as development scope a critical-reflexive analysis about the black people and their struggle for inclusive citizenship. In this sense, either objectively check the constitutional instruments and principles that mark such circumstance, so that such social niche has full access to all legal rights protected by the law, such as education, health, transportation and other fundamental rights. Thus, the article is divided into three structures, the first one to point out racial discrimination from a historical and cultural point of view; the second is to look at the rise, development and social transformation of the people black in the contemporaneity. Finally, the last axis has as a presupposition to verify the constitutional principles that mark an inclusive citizenship, based on the observation of the ADPF \# 186. For the making of the present work, the method of hypothetico-deductive approach, based on the constitutional premises, as well as method of historical and functionalist approach. Corroborating such methods was implemented the use of the research technique based on documentary source and bibliographic research. In preliminary results the full understanding of the relevant use of affirmative actions, legal argument potentially extracted from ADPF $\mathrm{n}^{\circ} 186, \mathrm{RE} \mathrm{n}^{\circ} 597.285 / \mathrm{RS}$ and $\mathrm{ADC} \mathrm{n}^{\circ}$ 41, is verified, which propose the assertion of full effectiveness of such instruments as beacons of a citizen inclusion from the constitutional beacons and fundamental rights.

Key words: Rise. Citizenship. Development. Black People. Constitucional Principle.

\section{Introdução}

O presente trabalho destina-se a promover uma condução reflexiva com base na verificação do povo negro na sociedade hodierna, reverberando acerca das transformações sociais ocorridas, sobretudo nos últimos anos, para poder tratar acerca de sua ascensão em camadas da sociedade brasileira e, desta forma, possibilitar uma verificação das significativas mudanças vistas na sociedade, cultura, economia e outras searas. Nessa senda, de acordo com a visão preconceituosa e marcado por estereótipos nocivos ao pleno desenvolvimento do indivíduo social, colocou-se o povo negro perante a sociedade de maneira altamente discriminatória, situação que se iniciou, ainda, no período colonial e, posteriormente, imperial, estendendo-se à república e perdurando com resquícios prejudiciais até os dias de hoje.

Logo, com base nessa perspectiva, sobre as relações preconceituosas e excludentes dentro de sua formação, que a presente pesquisa possui como centro estruturante e de desenvolvimento apresentar uma pesquisa que teve como escopo verificar como os princípios constitucionais podem balizar uma efetiva cidadania inclusiva dessa seara social, a fim de garantir que os mesmos tenham o pleno acesso a bens jurídicos tutelados pelo ordenamento, enquanto direitos e garantias.

Assim, com base nesse contexto, em sede de objetivos específicos a serem desenvolvidos com a presente pesquisa, em um primeiro eixo temático, o trabalho destina-se a realizar um retrospecto acerca da discriminação racial no Brasil, tendo como alicerce o prisma histórico e cultural. Do mesmo modo, em uma segunda seção, o trabalho promove observação acerca da ascensão, desenvolvimento e transformação do povo negro na esfera social contemporânea, permeando pressupostos de conquistas e novas configurações.

Por fim, o terceiro e último eixo temático do presente artigo tem como objetivo desenvolver o ponto de confluência existente entre a necessidade de uma cidadania inclusiva, a qual só será efetivada com base na potencial observância e respeito aos princípios constitucionais. Nessa mesma senda, tendo como suporte o entendimento ora explorado, será observado os argumentos expostos na ADPF n ${ }^{\circ} 186$ e as diretrizes que puderam cristalizar a efetivação das ações afirmativas como instrumentos potencializadores da igualdade material.

No que diz respeito ao aporte teórico que será utilizado na consecução e desenvolvimento do artigo em tela, conta-se com uma estrutura consubstanciada em autores de viés constitucionalista, de modo a contri- 
buir na solidificação do entendimento e nas nuances dos princípios constitucionais, bem como legislação e doutrina jurídica pertinente ao assunto ora tratado. Igualmente se estende tal premissa para os autores que serão utilizados no tratamento da discriminação do povo negro e suas lutas por direitos e inclusão efetiva.

Do ponto de vista metodológico, o artigo conta com o método de abordagem hipotético-dedutivo, o qual se justifica a parti do olhar do panorama discriminatório pelo qual o povo negro ainda está imbuído no Brasil, de modo a constatar que os princípios constitucionais podem ser instrumentos exponenciais e extremamente úteis a fim de garantir uma efetiva cidadania inclusiva dessa seara social e o respeito aos seus direitos e garantias esculpidos na Constituição Federal de 1988.

Conjuntamente ao método de abordagem elencado, coaduna-se a utilização do método de procedimento histórico e funcionalista, visto que o primeiro se justifica a partir de uma necessária observância do retrospecto histórico de luta e discriminação vivenciado pelo povo negro na sociedade passada e também contemporânea, ao passo que o método funcionalista, que tem o condão de ser mais interpretativo do que efetivamente investigativo, contribui ao corroborar com o novo panorama de ascensão e desenvolvimento do povo negro na morfologia social da atualidade. Combinados com tais métodos utiliza-se a técnica de pesquisa baseada em fonte documental e bibliográfica, a partir de escritos, tais como textos, notícias, doutrina, bem como, legislação pertinente e doutrina jurídica.

\section{A discriminação racial no Brasil: um olhar a partir do panorama histórico, cultural e jurídico}

A discriminação racial no Brasil constitui-se de um grave problema que circunda diversos vieses, matizes e compassos de entendimento, uma vez que seu alicerce teórico diz respeito a uma visão construída tanto social como historicamente. Nesse sentido, cumpre um olhar acerca desse panorama, travando uma análise reflexiva acerca do prisma histórico e cultural desse meandro.

Sendo assim, inicialmente cumpre reportar que é legado do pensamento político clássico o Princípio da Igualdade de todos perante as leis, o qual está solenemente proclamado na Declaração dos Direitos do Homem e do Cidadão de 1789. A partir dessa baliza jurídica, entende-se que todos os cidadãos devem estar submetidos às mesmas leis, independentemente de suas diferenças de classe, gênero, etnia, procedência regional, convicção religiosa ou política. Da mesma forma, tais cidadãos devem gozar dos mesmos direitos assegurados constitucionalmente, uma vez que as leis não podem discriminar privilégios, e, dessa forma, promover a exclusão de uns em benefício de outros ${ }^{1}$.

Muito embora os diplomas jurídicos edifiquem, a partir de arcabouço normativo tal igualdade, esta não se perfaz quando se materializa a vivência dentro do lócus social. Ou seja, a discriminação, seja por credo, religião, gênero, orientação sexual e, especificamente, racial, objeto de verificação nesse eixo temático, acontece de forma velada e muito fortemente acontece de forma explícita em diversos contextos da sociedade atual.

Nesse contexto, se levanta a guisa de discussão acerca das críticas às teorias evolucionistas como a Teoria de Spencer, o determinismo racial de Lombroso e o darwinismo social, que apostaram em uma continuidade entre dados físicos e morais, os quais afetam a possibilidade de uma discussão acerca da discriminação racial calcada na história dos conflitos entre povos decorrentes das diferenças fenotípicas, conforme conceituado por Darwin (1809-1882). Logo, é possível elencar uma discriminação racial calcada, sobretudo em conceituações históricas, fundamentadas em análise especialmente fenotípica, tendo por base alguns dados

\footnotetext{
ADORNO, Sergio. Discriminação Racial e Justiça Criminal em São Paulo. In: ADORNO, S. A criminalidade negra no banco dos réus: discriminação e desigualdade no acesso à justiça penal. Relatório de Pesquisa. Acordo NEV/USP-Geledés (Instituto da Mulher Negra). São Paulo: Núcleo de Estudos da Violência, 1994, p. 46. Disponível em: https://edisciplinas.usp.br/pluginfile.php/203942/ mod_resource/content/1/Adorno.pdf. Acesso em: 01 fev. 2019.
} 
e estudos nesse sentido, o que propuseram construções também de natureza social, política, econômica e jurídica que permanecem até a contemporaneidade.

Nesse contexto, o conceito de raça, enquanto um fator determinado biologicamente, não é mais considerado pela maioria das áreas do conhecimento, sejam a das humanas ou mesmo da genética ${ }^{2}$. Entretanto, o uso desse conceito como forma de distinguir os grupos humanos não deixou de existir ${ }^{3}$, mesmo tendo a sua vertente biologizante do século XIX suplantada por estudos sobre esse tema ${ }^{4}$.

Assim, atualmente é possível encontrar a conceitualização da chamada raça social, que se apoia em marcadores fenotípicos de determinados grupos. Tal forma de sistematização é diferente das apontadas pelas teorias racionalistas e biológicas do século XIX, pois não se amparam em critérios genéticos ${ }^{5}$. Todavia, essa forma de separar grupos tendo como aceitação e distinção a cor da pele, ainda hoje é utilizada no tecido social como meio de caracterizar as diferenças entre grupos humanos, e é identificado por alguns autores como sendo uma construção específica de raça ${ }^{6}$.

Nessa mesma senda, Silvério ${ }^{7}$ destaca:

Raça pode significar um grupo de pessoas que são socialmente definidas pelas suas marcas físicas exteriores como, por exemplo, a pigmentação da pele. Para evitar confusão, alguns autores especificam "raça social" quando usam o termo raça com este significado, isto é, de um grupo social definido por visibilidade somática.

Nessa circunstância, uma forma de autoengano tem constituído um obstáculo sério ao avanço da sociedade, tanto no que diz respeito ao Brasil quanto em países como a África do Sul. Trata-se da chamada democracia racial, uma vez que esta se constitui em um mito que ajuda a estruturar uma suposta falta de conflito nas relações raciais, e consubstancia o discurso conservador que nega a promoção de políticas afirmativas voltadas para a população negra ${ }^{8}$. Quer dizer, essa visão do Brasil como um paraíso racial ainda serve como argumento para aqueles que não reconhecem ou não admitem que, historicamente, a população brasileira sempre esteve em desvantagem para a competição por posições que poderiam lhe dar algum tipo de mobilidade na obtenção de ganhos ou de posição social, que sempre foi majoritariamente dos brancos?.

No mesmo entendimento, pontua Rigon ${ }^{10}$ :

Consciência negra? Somos um país de mestiços! Não sei qual é a dessa gente que quer transformar nosso país em uma nação dividida entre brancos e negros. Somos a mistura de dois ou mais a soma de diversas outras etnias.

Logo, com essa ideia de identidade nacional calcada na miscigenação entre os diferentes povos que formaram o país ${ }^{11}$, sem ter a atuação estatal que pudesse segregar, de forma clara e institucionalizada, apresenta uma impressão de que o Brasil não possui problemas relacionados ao racismo ${ }^{12}$, assim como notadamente

\footnotetext{
2 MAIO, Marcos Chor. O Brasil no concerto das nações: a luta contra o racismo nos primórdios da UNESCO. 1998. Disponível em: http://www.scielo.br/scielo.php?script=sci_arttex\&pid. Acesso em: 02 fev. 2019.

3 SILVÉRIO, Valter Roberto. Raça e racismo na virada do milênio: os novos contornos da racialização. Tese (Doutorado em Sociologia) - Instituto de Filosofia e Ciências Humanas, Unicamp, Campinas, 1999.

4 HOFBAUER, Andréas. Uma história de branqueamento ou o negro em questão. São Paulo: Unesp, 2005.

5 GUIMARÃES, A. S. A. Racismo e anti-racismo no Brasil. São Paulo: Editora 34. 1999.

6 ASSIS, Marcelo Francisco de; AMORIM, Cleyde Rodrigues de. Racismo@online.com.br. Revista da ABPN, v. 2, n. 4, p. 131-149, mar./ jun. 2011.. Disponível em: http://www.abpnrevista.org.br/revista/index.php/revistaabpn1/article/view/325/299. Acesso em: 02 mar. 2019.

7 SILVÉRIO, Valter Roberto. Raça e racismo na virada do milênio: os novos contornos da racialização. Tese (Doutorado em Sociologia) - Instituto de Filosofia e Ciências Humanas, Unicamp, Campinas, 1999. p. 56.

8 SILVÉRIO, Valter Roberto. Raça e racismo na virada do milênio: os novos contornos da racialização. Tese (Doutorado em Sociologia) - Instituto de Filosofia e Ciências Humanas, Unicamp, Campinas, 1999. p. 138.

9 HASENBALG, Carlos. Discriminação e desigualdades raciais no Brasil. Belo Horizonte: UFMG; Rio de Janeiro: UPERJ, 2005.

10 RIGON, Angelo. Opinião e notícia. Disponível em: http://angelorigon.blogspot.com. Acesso em: 01 jun. 2018.

11 TELLES, Edward. Racismo à brasileira: uma nova perspectiva sociológica. Rio de Janeiro: Relume Dumará, 2003.

12 DAMATTA, Roberto Augusto. Relativizando: uma introdução à Antropologia Social. Petrópolis, RJ: Vozes, 1984.
} 
aconteceu como países como os Estados Unidos ou a África do Sul ${ }^{13}$, que deflagraram uma circunstancial segregação.

Entretanto, graças aos esforços perseverantes de décadas do movimento social negro brasileiro, uma parte crescente da sociedade tem identificado a democracia racial como uma visão perigosa ${ }^{14}$. Esse processo convergiu para a redução de imensas desigualdades sociais, fundando as bases para um mundo ético regido pelo reconhecimento do outro como sujeito de direitos. Com base nessa perspectiva, estabeleceu-se um nexo histórico entre justiça social e igualdade jurídica ${ }^{15}$.

Essa concepção de que não existe conflito étnico racial no Brasil está enraizada na sociedade desde a abolição da escravatura, conforme destaca Assis e Amorim ${ }^{16}$. Durante aquela época, o paradigma pensado para uma país democrático estabelecia um conjunto social em que a presença do negro se delimitava a um espaço circunscrito, tento na figura do branco o sujeito dominante ${ }^{17}$. Isso aconteceu porque, mesmo com o fim da escravidão, o negro continuou sendo privado de políticas e direitos que eram teoricamente tangíveis a todos os cidadãos. A esse aspecto, Fernandes ${ }^{18}$ afirma que "o negro não era repelido frontalmente, mas, também não era aceito sem restrições, abertamente, de acordo com as prerrogativas sociais que decorriam de sua nova condição jurídico política”.

Sendo assim, consoante Assis e Amorim ${ }^{19}$, a inserção do negro enquanto ator social ficou vinculado à imagem do ex-escravo e, mesmo com a abolição da escravatura anos mais tarde, ele continuou estigmatizado, sem ser reconhecido concretamente como novo cidadão dotado de direitos e prerrogativas a serem alcançadas pelo Estado.

Entretanto, com a evolução e desenvolvimento social, abrem-se novos espaços para a instituição de um debate fecundo sobre todos os aspectos da construção de uma nova sociedade e uma nova nação brasileira no século XXI. Considerando-se os casos compostos pelos Estados Unidos durante a década de 1960 e 1970, bem como Cuba revolucionária a partir de 1959, e a África do Sul, com o desmantelamento do sistema de apartheid, a partir de 1992, o Brasil se converteu, apenas, no quarto país, desde a Segunda Guerra Mundial, a lançar uma tentativa de reforma de sua ordem sócio racial ${ }^{20}$.

Logo, o Brasil, atualmente, sinaliza aos olhos do mundo possibilidades de transformações importantes. De natureza inédita a Lei 10.639/0321, potencialmente transformadora, torna obrigatório o ensino da história e cultura afro-brasileira nos estabelecimentos públicos e particulares, incluindo o estudo da história da África e dos africanos. Se aplicada com o requerido vigor e rigor, essa medida poderia ter um impacto permanente nas consciências das gerações vindouras. Dessa forma, a implementação dessa lei pioneira abriu uma nova porta para a sociedade inteira reavaliar as bases da fundação do Brasil como entidade histórica nos tempos modernos, e reconsiderar as relações étnico-raciais nele travadas.

\footnotetext{
13 Ibidem, 2003.

14 MUGANGA, Kabengele. Algumas considerações sobre "raça", ação afirmativa e identidade negra no Brasil: fundamentos antropológicos. Revista USP, São Paulo, n. 68, p. 46-57, dez./ fev. 2005-2006.

15 ADORNO, Sergio. Discriminação Racial e Justiça Criminal em São Paulo. In: ADORNO, S. A criminalidade negra no banco dos réus: discriminação e desigualdade no acesso à justiça penal. Relatório de Pesquisa. Acordo NEV/USP-Geledés (Instituto da Mulher Negra). São Paulo: Núcleo de Estudos da Violência, 1994, p. 46. Disponível em: https://edisciplinas.usp.br/pluginfile.php/203942/ mod_resource/content/1/Adorno.pdf. Acesso em: 02 fev. 2019.

16 ASSIS, Marcelo Francisco de; AMORIM, Cleyde Rodrigues de. Racismo@online.com.br. Revista da ABPN, v. 2, n. 4, p. 131-149, mar./jun. 2011. Disponível em: http://www.abpnrevista.org.br/revista/index.php/revistaabpn1/article/view/325/299. Acesso em: 02 fev. 2018. p. 139.

17 ASSIS, Marcelo Francisco de; AMORIM, Cleyde Rodrigues de. Racismo@online.com.br. Revista da ABPN, v. 2, n. 4, p. 131-149, mar./jun. 2011. Disponível em: http://www.abpnrevista.org.br/revista/index.php/revistaabpn1/article/view/325/299. Acesso em: 01 jun. 2018. p. 139.

18 FERNANDES, Florestan. A integração do negro na sociedade de classes. 3. ed. São Paulo: Ática, 1978.

19 FERNANDES, Florestan. A integração do negro na sociedade de classes. 3. ed. São Paulo: Ática, 1978. p. 139-140.

20 WEDDERBURN, Carlos Moore. O racismo através da história: da antiguidade à modernidade. Copyright, 2007.

21 Altera a Lei no 9.394, de 20 de dezembro de 1996, que estabelece as diretrizes e bases da educação nacional, para incluir no currículo oficial da Rede de Ensino a obrigatoriedade da temática "História e Cultura Afro-Brasileira", e dá outras providências.
} 
E é o Princípio de Necessidade de evolução da raça que norteará os pensadores brasileiros, muitos desses influenciados pelas ideias europeias e de pensadores que vinham ao Brasil para compreender a miscigenação, como mencionados por Schwarcz $z^{22}$. Este afirmava "quem quiser ter um exemplo do que é a degeneração e a mistura racial extremada, venha ao Brasil e terá a prova da degeneração local”.

Nesse concernente, a discriminação racial, sobretudo dos negros, é um fenômeno eminentemente não conceitual, ele deriva de fatos históricos concretos ligados a conflitos reais ocorridos na história dos povos, uma vez que a noção forjada durante o recente período sombrio da história humana, constituída pela conquista das Américas e a escravização dos africanos nestas terras, ainda é mantida, uma vez que a noção que ainda permeia ideário conceitual refere-se ao fato de que os povos de raça negra desempenharam papel irrisório na longa e complexa trama da humanidade. Nesse sentido, Wedderburn ${ }^{23}$ cita que os negros teriam sido meros coadjuvantes na história, inclusive no seu próprio continente de origem.

Nesse sentido, mesmo após a abolição da escravatura, os brancos continuaram a ocupar a posição de senhores e os negros exerceram, ainda, pertinências dos escravos. Nesse aspecto, Fernandes ${ }^{24}$ esclarece:

$\mathrm{Na}$ medida em que a ordem social competitiva e a urbanização estavam em plena emergência (...) os negros e os mulatos ficaram à margem ou se viram excluídos da prosperidade geral (...) porque não tinham condições para entrar nesse jogo e sustentar suas regras. (...) Viveram dentro da cidade, mas não progrediam com ela e através dela. Constituíram uma congérie social (...) e só partilhavam em comum uma existência árdua, obscura e muitas vezes deletéria.

Dando sequência, a partir das ações dos movimentos sociais em 1978, surgiu o Movimento Negro Unificado, que passou a coordenar, em todo o país, outras entidades que surgiam com o propósito de arregimentar forças contra o racismo ${ }^{25}$ ou qualquer outra forma de violência ou preconceito. O mais pertinente é destacar o papel do negro na história, os distintos movimentos de resistência cometidos, quais circundam a ação das confrarias religiosas, os quilombos, o movimento abolicionista, as insurreições que contaram com expressiva participação dos negros em diversas lutas pós-abolição, a urbanização, a estratificação. Todo esse contexto, bem como a partir da modernidade capitalista impulsionou o negro a ascender, mesmo que de forma tímida no tecido social.

Nessa senda, ao longo dos séculos, abordaram-se os conceitos sobre raças e classes sociais e alguns constataram que concepções racistas foram utilizadas para legitimar o sistema mercadológico escravocrata da época colonial. Esse sistema ainda perdura com outra roupagem, a do capitalismo, para o fim de viabilizar as desigualdades sociais. O descaso governamental em ocultar a contribuição do negro na construção nacional, bem como o preconceito racial, existe por meio de algumas condutas e verificações, também a partir de outras revisões bibliográficas, ou seja, pode-se constatar que as discriminações sejam raciais ou não são designadas e recontadas ao longo dos anos no teor que prepondera com base nas distintas desigualdades sociais ${ }^{26}$.

Se o racismo resiste hoje com a virulência que possui, expandindo-se cada vez mais, apesar de todos os esforços morais e culturais e de todos os avanços no conhecimento científico sobre as diferenças humanas, é porque tem se convertido ao longo do tempo numa realidade tenaz, arraigada na consciência e na prática social. Além disso, as relações raciais engendradas no Brasil tomaram rumos específicos, quais sejam baseadas em um formalismo e patriotismo inerentes à cultura do país, o que pressupõem que elas vêm ao longo da história corroborando a manutenção do sistema vigente, em que se tem um problema que é percebido, mas não admitido ${ }^{27}$.

\footnotetext{
22 SCHWARCZ, Lilia Moritz. Espetáculo da Miscigenação. Revista Estudos Avançados - USP, São Paulo, v. 8, n. 20 1996. p. 171. Disponível em: http://www.revistas.usp.br/eav/article/view/9652/11222. Acesso em: 02 fev. 2019.

23 WEDDERBURN, Carlos Moore. O racismo através da história: da antiguidade à modernidade. Copyright, 2007.

24 FERNANDES, Florestan. A integração do negro na sociedade de classes. 3. ed. São Paulo: Ática, 1978. p. 99.

25 O racismo é qualquer pensamento ou atitude que separam as raças humanas por considerarem algumas superiores a outras.

26 LOPES, Eliana Marta Teixeira; GALVÃO, Ana Maria de Oliveira. História da Educaşão. 2. ed. Rio de Janeiro: DP\&A, 2005. p. 186.

27 DAMATTA, Roberto Augusto. Relativizando: uma introdução à Antropologia Social. Petrópolis, RJ: Vozes, 1984.
} 
Logo, o racismo seria um fenômeno estático, que recuaria constantemente diante da educação, do crescimento econômico - o chamado desenvolvimento - da expansão dos conhecimentos científicos e das mudanças tecnológicas. Segundo essa visão, o racismo teria suas origens na ignorância e na ausência de parâmetros científicos para examinar as diferenças humanas. O sociólogo brasileiro Octávio Ianni, pouco antes de falecer, pontuou, com extraordinária presciência, a falácia dessa crença. Alertou para a extraordinária expansão, em escala planetária, do racismo nas diversas sociedades. A esse respeito, o referido autor pontua ${ }^{28}$ :

Mais uma vez, no início do século XXI, muitos se dão conta de que está novamente em curso um vasto processo de racialização do mundo. O que ocorreu em outras épocas, a começar pelo ciclo das grandes navegações, descobrimentos, conquistas e colonizações, torna a ocorrer no início do século XXI, quando indivíduos e coletividades, povos e nações, compreendendo nacionalidades, são levados a dar-se conta de que se define, também ou mesmo principalmente, pela etnia, a metamorfose da etnia em raça, a transfiguração da marca ou traço fenotípico em estigma.

Nesse ponto, o racismo constitui fator permanente na sociedade na medida em que ele é o produto de uma longa elaboração histórica e não intelectual. É por isso que a luta pela diversidade e pluralismo racial, a luta contra o racismo, deve, também, ser um fator permanente da sociedade, articulando-se igualmente e de maneira cambiante. A luta permanente, multiforme e em todos os níveis contra o racismo — seja qual for sua forma, o contexto ou a instância na qual se manifeste — é a única estratégia possível e viável. Dessa feita, verifica-se que a discriminação racial no Brasil é um problema grave engendrado historicamente e perpassado culturalmente, lesando uma extrema gama de indivíduos. Nesse contexto, Assis e Amorim ${ }^{29}$ destacam que questões como preconceito e política são vistas como algo que foge ao mundo concreto, real, como se a população, de forma geral, estivesse à margem de tudo isso.

Todavia, ao fim e ao cabo, é também perceptível compassos de mudança, uma vez que novos alicerces sociais estão sendo construídos no Brasil, calcados, sobretudo, no crescimento econômico, no nível de escolaridade e educação, bem como no acesso a bens imateriais e culturais. Assim, se verifica que é possível desconstruir alguns paradigmas nocivos e altamente prejudiciais. Nesse contexto, se destina o eixo temático a seguir, com objetivo de verificar a transformação e o desenvolvimento social com base no prisma da ascensão dos negros na contemporaneidade. É o que se passa a verificar.

\section{A transformação, ascensão e o desenvolvimento social do povo negro na contemporaneidade}

A partir do século XIX, o negro emerge, enquanto influente social ativo, em distintas perspectivas, combatendo e vivenciando contraditoriamente o racismo num país originalmente escravocrata. Nesse sentido, passa a desempenhar funções que, até então, usualmente, não fazia ou estava proibido, passa a ser, efetivamente, um sujeito de direitos, o que lhe permissionará desenvolvimento intelectual, científico, político, econômico e jurídico.

Com esses enfrentamentos sociais, ocorridos durante séculos, os descendentes da escravidão ficaram à margem da sociedade e perpetuaram a maioria, até nos dia de hoje, alguns aspectos. Todavia, uma emergente minoria dos negros passou a ascender de maneira econômica, política, acadêmica, dentre outros campos da sociedade.

Nesse contexto, Pereira ${ }^{30}$ esclarece:

28 IANNI, Octavio. A dialética da globalização: teorias da globalização. Rio de Janeiro: Civilização Brasileira, 2004. p. 22.

29 ASSIS, Marcelo Francisco de; AMORIM, Cleyde Rodrigues de. Racismo@online.com.br. Revista da ABPN, v.2, n. 4, mar./jun. 2011. p. 142. Disponível em: http://www.abpnrevista.org.br/revista/index.php/revistaabpn1/article/view/325/299. Acesso em: 02 fev. 2019.

30 PEREIRA, Caio Mário da Silva.Instituições de Direito Civil: direito de família.16. ed. Rio de Janeiro: Editora Forense, 2005. v. 5. p. 66. 
A ascensão social dos negros no Brasil, embora de maneira tímida, é fato. De cada seis negros que se movem na pirâmide social do país, cinco melhoram sua condição de vida. A população negra corresponde a um terço da classe média do país.

Logo, no contexto da ascensão social, tendo em vista a contradição que há em relação à estatística sobre o posicionamento do negro socialmente, o surgimento das classes e as desigualdades sociais, alguns negros resistem à discriminação e ao preconceito, bem como o racismo e emergem nessa sociedade visivelmente racista, preconceituosa e altamente complexa. Segundo Figueiredo, a mobilidade na esfera social é apontada para mudanças de comportamentos e valores dos sujeitos ou grupos, ou seja, tal conceito é verificado no processo de ascensão, e trata-se de uma característica de todos os indivíduos ou grupos que ascendem as mudanças e atitudes de ações ${ }^{31}$. Para a referida autora,

quando um indivíduo passa de uma ocupação de status baixo para uma ocupação de status mais alo de classe média, por exemplo, AL movimento tende a ser acompanhado de vários ganhos em ermos de oportunidades econômica, educacionais e sociais, assim como de mudança de valores, de atitudes e de horizonte cultural.

Portanto, com base nas citações anteriores, nessa forma de querer ser enxergado, tornando-se branco na classe média que se estabelece, o negro, também, se torna invisível por falta de posicionamento, frente à discriminação. No processo de desigualdade social o negro, em sua maioria, possui baixa escolaridade, dessa maneira, se depara com muitas barreiras para ascender socialmente, a dificuldade de se inserir no mercado de trabalho, com precárias qualificações, ressaltando o aumento da desigualdade socioeconômica ${ }^{32}$.

A segregação, a partir da cor da pele restringe as aspirações de mobilidade social. Nas últimas décadas, ocorreram no Brasil mudanças, a população preta e parda continua sofrendo desvantagens no mercado de trabalho, em virtude do racismo. Por meio dessa ideologia racista, a identidade negra é abalada por sinal de inferioridade e desqualificação na esfera social. A qualificação ou desqualificação desse sinal não é assunto da aspiração dos diversos grupos da sociedade, no ambiente das relações sociais, buscam uma subversão sobre o fazer social de cada um de nós ${ }^{33}$.

Para tanto, com o esclarecimento econômico sociopolítico, no período de transição para uma sociedade de classes, visavam manter a distância entre o branco e o negro, preconceito e discriminação, nas condições histórico-sociais, preservavam as estruturas elaboradas sob o regime escravocrata. Mudanças de comportamentos e valores do negro que ascende, pontuou a construção da classe média negra, mas, ao mesmo tempo, fechou as possibilidades de que o negro e o mulato fossem beneficiários dos direitos e garantias sociais.

O racismo institucional, ou modalidade institucional, é claramente demonstrado em dados oficiais, como os fornecidos pelo Instituto Brasileiro de Geografia e Estatística (IBGE). O negro, o índio, o judeu, o cigano, os retirantes, os boias frias, os garimpeiros, os peões, os mendigos, os bêbados, os gigolôs, os homossexuais, a mulher — sobretudo negra — e toda sorte de marginalizados, destituídos e enjeitados são oculta ou abertamente discriminados em nosso sistema de trabalho, na Justiça, na Economia, na Política e nas demais instituições.

Sendo assim, nesse contexto que se inseriu o negro na atualidade, buscando melhores oportunidades, de acesso ao trabalho, bem como escolaridade, melhores salários e despontando até mesmo em meandros como a política, altos cargos de liderança e de aspectos econômicos. Nesse sentido, o que se verifica na prática ainda é uma resistência muito forte a esse povo negro usufruir de espaços — público ou privados — que hegemonicamente estão restritos aos brancos. Isso se deve a arraigados aspectos de natureza social, histórica e cultural.

31 FIGUEIREDO, Rita Vieira. Políticas de inclusão: escola gestão da aprendizagem na diversidade. In: ROSA, Dalva E.; SOUZA, Vanilton C. Gonçalves e. Políticas organiz̧ativas e curriculares, educação inclusiva e formação de professores. Rio de Janeiro: DP\&A, 2002 , p. 34.

32 BASTIDE, Roger. Le rêve, la transe et la folie. 1972, p. 20.

33 HASENBALG, Carlos. Discriminação e desigualdades raciais no Brasil. Rio de Janeiro, 1988. 
Logo, dentro desse meandro, se verifica a necessidade de uma aplicação mais lógica e coerente do Princípio da Dignidade Humana como instrumento balizador da luta pela cidadania, mas esta não meramente ilustrativa, mas sim firmada no compromisso inclusivo, alicerçada em políticas públicas de educação, para que se alcancem melhores condições de vida e direitos que sejam também atinentes a essa parcela social, de modo a dar vez e vOz aos indivíduos que, por muito tempo, estiveram segregados ou à margem de direitos e oportunidades na sociedade branca e escravocrata. Logo, é sobre tal perspectiva que o próximo tópico passa a tratar.

\section{Os princípios constitucionais e o povo negro na luta pela cidadania inclusiva: uma perspectiva com base na ADPF $n^{\circ} 186$}

Preliminarmente, cabe referir que o eixo em tela tem como preocupação principal tratar acerca da visualização do povo negro no Brasil em uma perspectiva principiológica, a partir da Constituição Federal de 1988, com o condão de trabalhar o conceito de cidadania inclusiva em uma análise da ADPF n 186 e a utilização de tais princípios de baliza constitucional para efetivar tais mandamentos com base na criação de mecanismos específicos de igualdade material, a exemplo das ações afirmativas.

Sendo assim, na Constituição da República Federativa do Brasil de 1988, em seu artigo $5^{\circ}$ caput, verifica-se o tratamento dispensado pelo documento máximo do ordenamento jurídico para o Princípio da Igualdade, todavia trata-se da igualdade formal, que não estabelece distinção alguma entre as pessoas, de modo que todos devem ser tratados igualmente ${ }^{34}$. Entretanto, segundo Maia ${ }^{35}$, em outra circunstância tem-se a igualdade material, também chamada de substancial ou aristotélica, a qual o filósofo Aristóteles, 300 A.C, proferiu que "devemos tratar os iguais igualmente e os desiguais desigualmente, na medida de suas desigualdades", que se tornou, posteriormente, o conceito jurídico de igualdade material, onde, tratamento diferenciado é dado a certos grupos de pessoas que se encontram em situação de vulnerabilidade ou que necessitem de ferramentas que possibilitem o alcance efetivo a direitos e garantias.

Nessa trajetória, Aristóteles ${ }^{36}$ aponta:

pensa-se, por exemplo, que justiça é igualdade — e de fato é, embora não o seja para todos, mas somente para aqueles que são iguais entre si; também se pensa que a desigualdade pode ser justa, e de fato pode, embora não para todos, mas somente para aqueles que são desiguais entre si. Para pessoas iguais o honroso e justo consiste em ter a parte que lhes cabe, pois nisto consistem a igualdade e a identificação entre pessoas; dar, porém, o desigual a iguais, e o que não é idêntico a pessoas identificadas entre si, é contra a natureza, e nada contrário à natureza é bom.

Nesse contexto, impende-se que as pessoas são diferentes "em sua personalidade e em sua ambição, diferentes em sua condição cultural e em sua capacidade de produção econômica" conforme diretrizes apontadas por Czajkowski $i^{37}$. Logo, nesse meandro Frischeisen ${ }^{38}$ aponta que "as condições de igualdade precisam ser produzidas por meio de ações que o Poder Público realiza, visando o efetivo exercício da igualdade, base

\footnotetext{
34 Esclarece o dispositivo constitucional que: Art. $5^{\circ}$ Todos são iguais perante a lei, sem distinção de qualquer natureza, garantindose aos brasileiros e aos estrangeiros residentes no País a inviolabilidade do direito à vida, à liberdade, à igualdade, à segurança e à propriedade [...].

BRASIL. [Constituição (1988)]. Constituição da República Federativa do Brasil. Brasília, DF: Senado Federal, 1988.

35 MAIA, Marcos Chor. O Brasil no concerto das nações: a luta contra o racismo nos primórdios da UNESCO. 2017. p. 60. Disponível em: http://www.scielo.br/scielo.php?script=sci_arttex\&pid. Acesso em: 02 fev. 2019.

36 ARISTÓTELES. Política. 3. ed. Brasília: Universidade de Brasília, 1997, p. 228.

37 CZAJKOWSKI, Rainer. A crise do princípio da isonomia e a propriedade. In: RAMOS, Carmem Lucia Silveira. (coord.) Direito civil constitucional: situações patrimoniais. Curitiba: Juruá, 2002. p. 190.

38 FRISCHEISEN, Luiza Cristina Fonseca. Políticas públicas: a responsabilidade do administrador e o Ministério Público. São Paulo: Max Limonad, 2000. p. 58.
} 
de toda a ordem social". Do mesmo modo, Suiama ${ }^{39}$, coloca que "a identidade de cada um não é um dado, mas sim algo construído a partir das relações que se estabelecem nas sociedades humanas".

Desse modo, são cada vez mais necessárias as interferências estatais, por meio do ordenamento jurídico para promover a igualdade entre os indivíduos sociais e eliminar as desigualdades. Sobre tal compasso, Streck ${ }^{40}$ aponta:

Esse novo modelo constitucional supera o esquema da igualdade formal rumo à igualdade material, o que significa assumir uma posição de defesa e suporte da Constituição como fundamento do ordenamento jurídico e expressão de uma ordem de convivência assentada em conteúdos materiais de vida e em um projeto de superação da realidade alcançável com a integração das novas necessidades e a resolução dos conflitos alinhados com os princípios e critérios de compensação constitucionais.

Nesse aspecto, a igualdade material trata-se de uma das mais importantes normas jurídicas e requer esforço dos intérpretes para uma aplicação (indispensável aplicação) adequada ${ }^{41}$. Esta exige de quem a defina uma tomada de posição (política, ideológica), com o que, numa expressão de Canotilho ${ }^{42}$, "desafivelam-se as máscaras" e revela-se a intenção ("o tom e o dom”). Verifica-se, então, que a interpretação desses princípios está alicerçada muitas vezes nos conceitos de hermenêutica constitucional, haja vista a necessidade de uma exegese acerca de alguns princípios e regras jurídicas constitucionais que carecem de uma determinabilidade.

A igualdade se expressa, dessa forma, em termos jurídicos, sob a forma de norma jurídica do tipo "princípio", que se caracterizam segundo critérios apontados por Canotilho ${ }^{43}$, por um grau de abstração relativamente elevado e por serem vagos e indeterminados, pois dependerem de "mediações concretizadoras" por terem um caráter de fundamentalidade no sistema, por traduzirem "exigências de justiça" e por serem fundamento de regras ("natureza normogenética"), conforme declara Rothenburg ${ }^{44}$. Por ser princípio jurídico, a igualdade tem sua aplicação condicionada por outras normas (em que se incluem as circunstâncias fáticas), podendo aplicar-se em maior ou menor medida um "mandamento de otimização ${ }^{45 "}$.

Desse modo, no mesmo segmento, é possível prescrever algumas formas pelas quais esse princípio de igualdade é perfectibilizada, como a regra que veda "instituir tratamento desigual entre contribuintes que se encontrem em situação equivalente" (Constituição brasileira, art. 150, II), a "proibição de diferença de salários, de exercício de funções e de critérios de admissão por motivo de sexo, idade, cor ou estado civil", (Constituição, art. $7^{\circ}, \mathrm{XXX}$ ), logo, em tais exemplos, é possível visualizar a sedimentação de tal baliza jurídica constitucional.

Também está elencado no rol de Princípios Fundamentais da Constituição Federal de 1988, art. $1^{\circ}$ ao $4^{\circ}$, o Princípio da Dignidade da Pessoa Humana, um valor moral e espiritual inerente à pessoa, ou seja, todo ser humano é dotado desse preceito, e tal constitui o Princípio máximo do Estado Democrático de Direito, a cidadania, como procurou conceituar num prisma jurídico, o Professor Ingo Wolfgang Sarlet ${ }^{46}$ :

Temos por dignidade da pessoa humana a qualidade intrínseca e distintiva de cada ser humano que o faz

\footnotetext{
39 SUIAMA, Sergio Gardenghi. Identidades, diferenças. Boletim cientifico - Escola Superior do Ministério Público da União, Brasília: ESMPU - Escola Superior do Ministério Público da União, n. 2, abr./jun. 2004. p. 132.

40 STRECK, Lenio Luiz. Hermenêutica jurídica $e(m)$ crise: uma exploração hermenêutica da construção do Direito. 3. ed. Porto Alegre: Livraria do Advogado, 2002. p. 283.

41 ROTHENBURG, Walter Claudios. Igualdade Material e Discriminação Positiva: O Princípio da Isonomia. Novos Estudos Jurídicos, v. 13, n. 2, 2008. p. 79.

42 CANOTILHO, José Joaquim Gomes. Estudos sobre direitos fundamentais. Coimbra: Coimbra, 2004. p. 129.

43 CANOTILHO, José Joaquim Gomes. Estado constitucional ecológico e democracia sustentada. In: GRAU, Eros Roberto; CUNHA, Sérgio Sérvulo da (coord.). Estudos de direito constitucional em homenagem a José Afonso da Silva. São Paulo: Malheiros, 2003. p. 166-167.

44 ROTHENBURG, Walter Claudios. Igualdade Material e Discriminação Positiva: o princípio da isonomia. Novos Estudos Jurídicos, v. 13, n. 2, 2008. p. 79.

45 ALEXY, Robert. La naturaleza de la filosofía del derecho. Doxa, Barcelona, n.26, 2003.

46 SARLET, Ingo Wolfgang. A eficácia dos direitos fundamentais. 7. ed. ver. atual. e ampl. Porto Alegre: Livraria do Advogado, 2007. p. 62.
} 
merecedor do mesmo respeito e consideração por parte do Estado e da comunidade, implicando, neste sentido, um complexo de direitos e deveres fundamentais que asseguram a pessoa tanto contra todo e qualquer ato de cunho degradante e desumano, como venham a lhe garantir as condições existenciais mínimas para uma vida saudável, além de propiciar e promover sua participação ativa e corresponsável nos destinos da própria existência e da vida em comunhão com os demais seres humanos.

De outra forma, a Professora Maria Helena Diniz ${ }^{47}$ buscou conceituar a dignidade da pessoa humana tendo por moldura o direito de família. Nesse caso a autora observou a necessidade de garantir o pleno desenvolvimento dos anseios e interesses afetivos dos membros familiares, por meio da garantia da assistência educacional aos filhos, com o objetivo de manter a familia perene e feliz. Nesse seguimento, destaca a autora ${ }^{48}$ :

É preciso acatar as causas da transformação do direito de família, visto que são irreversíveis, procurando atenuar seus excessos, apontando soluções viáveis para que a prole possa ter pleno desenvolvimento educacional e para que os consortes ou conviventes tenham uma relação firme, que integre respeito, tolerância, diálogo, troca enriquecedora de experiência de vida etc.

Sendo assim, o conceito da dignidade da pessoa humana permeia toda a Carta, tendo, no Art. $1^{\circ}$ inciso III, a costura perfeita entre o texto principal e o preâmbulo, pois, quando este fala de direitos individuais, de liberdade, de igualdade, de justiça e tudo sem preconceitos, aquele, traz como fundamento ou alicerce da Constituição a dignidade da pessoa humana, mais adiante, ainda, existe o Art. $4^{\circ}$, inciso II, trazendo os direitos humanos como regente da Republica e o Art. $5^{\circ}$, que fala da inviolabilidade do direito à vida, à liberdade, à segurança e à igualdade ${ }^{49}$. Nesse seguimento, a Constituição Federal ${ }^{50}$ apresenta:

Art. $1^{\circ}$ A República Federativa do Brasil, formada pela união indissolúvel dos Estados e Municípios e do Distrito Federal, constitui-se em Estado Democrático de Direito e tem como fundamentos: [...] III - a dignidade da pessoa humana;

Art. 4 A República Federativa do Brasil rege-se nas suas relações internacionais pelos seguintes princípios: [...]

II - prevalência dos direitos humanos;

Art. $5^{\circ}$ Todos são iguais perante a lei, sem distinção de qualquer natureza, garantindo-se aos brasileiros e aos estrangeiros residentes no País a inviolabilidade do direito à vida, à liberdade, à igualdade, à segurança e à propriedade [...].

Nessa perspectiva, é possível prescrever que, em muitos casos, a aplicação dos princípios constitucionais, como os que foram supracitados neste artigo, têm uma verdadeira confluência com a inclusão de segmentos sociais e também a diversidade. Logo, tratar a respeito de inclusão impende, necessariamente, tratar a respeito da cidadania. Esta trata como a qualidade ou condição de cidadão se perfaz pela prática dos direitos e deveres de um indivíduo em um Estado. Juridicamente se traduz como condição de pessoa que como membro de um Estado, se acha no gozo de direitos que lhe permitem participar da vida política, sendo um dos instrumentos de efetivação da cidadania inclusiva, é a educação ${ }^{51}$.

Essa inclusão na realidade brasileira tem como ponto de referência o acompanhamento sistemático no interior da escola, de modo que esse método sido reafirmado como estratégia recomendável no processo de integração escolar priorizando o processo coletivo, enfatizando a complexidade da sala de aula e também do ambiente escolar. Para se ter realmente uma escola inclusiva, são necessárias novas estruturas e novas competências, haja vista que os próprios professores devem ter uma formação que rompa com a polaridade existente entre educação comum e especial, tendo como referência básica a diversidade e o aprendizado da inclusão $0^{52}$, inclusão de todas as modalidades do tecido social, a exemplo do povo negro.

7 DINIZ, Maria Helena.Curso de Direito Civil Brasileiro:direito de família.22. ed. São Paulo: Editora Saraiva, 2007. v. 5. p. 18.

48 DINIZ, Maria Helena.Curso de Direito Civil Brasileiro:direito de família.22. ed. São Paulo: Editora Saraiva, 2007. v. 5.

49 SILVA, José Afonso. Curso de direito constitucional positivo. São Paulo: Malheiros, 2007. p. 89.

50 BRASIL. [Constituição (1988)]. Constituição da República Federativa do Brasil. Brasília, DF: Senado Federal, 1988.

51 SILVA, José Afonso. Curso de direito constitucional positivo. São Paulo: Malheiros, 2007. p. 91.

52 MANTOAN, Maria Tereza Eglér. Inclusão escolar: o que é? Por quê? Como fazer? São Paulo: Moderna, 2006. p. 81. 
Nesse contexto, a professora Maria Tereza Egler Mantoan ${ }^{53}$, assim, se manifestou:

A noção de base em matéria de integração é o princípio de normalização, que não sendo específico da vida escolar, atinge o conjunto de manifestações e atividades humanas e todos as etapas da vida das pessoas, sejam elas afetadas ou não por uma incapacidade, dificuldade ou inadaptação. A normalização visa tornar acessível às pessoas socialmente desvalorizadas condições e modelos de vida análogos aos que são disponíveis de um modo geral ao conjunto de pessoas de um dado meio ou sociedade: implica de um novo paradigma de entendimento das relações entre as pessoas fazendo-se acompanhar de medidas que objetivam a eliminação de toda e qualquer forma de rotulação.

Nesse panorama inclusivo, tentando ou buscando implementar a lógica de alguns princípios constitucionais como a Dignidade da Pessoa Humana e o Princípio da Igualdade material, universidades públicas, visando combater a discriminação racial existente no setor educacional, implantaram o sistema de cotas, a partir da política educacional de Ações Afirmativas, que consiste na concessão do direito a um percentual de vagas não submetida à concorrência ampla, para aqueles alunos que possuem características peculiares ligadas à cor, etnia ou classe social ${ }^{54}$.

Logo, sabe-se que as universidades públicas têm importante papel integrador, pois é onde se formam profissionais que ocuparão os cargos mais elevados da sociedade, tanto no âmbito público como no privado. No entanto, infelizmente, a realidade brasileira mostra que, nas universidades públicas e privadas, predomina uma classe privilegiada da sociedade, impossibilitando, assim, que as pessoas economicamente desfavorecidas tenham acesso a oportunidades melhores e possam ascender na vida ${ }^{55}$.

Todas as ações que visem estabelecer e aprimorar a igualdade entre todos os indivíduos sociais são dignas de apreço. É importante, no entanto, refletir sobre as possíveis consequências da adoção de políticas públicas que levem em consideração apenas o critério racial. Não se pode deixar que o combate ao preconceito e à discriminação em razão da cor da pele, fundamental para a construção de uma verdadeira democracia, reforce as crenças perversas do racismo e divida a sociedade em dois polos antagônicos: "brancos" e "não brancos" ou "negros" e "não negros ${ }^{56 "}$ " No concernente à própria legislação brasileira já avançou, uma vez que estabelece a punição para o crime de racismo e injúria racial ${ }^{57}$.

A política de reservas de vagas é uma possibilidade que não é totalmente estranha à Constituição vigente, podendo ser encontrado em seu art. 37, inciso VIII, ao qual menciona a reserva de percentual de cargos e empregos públicos para as pessoas portadoras de deficiência ${ }^{58}$. Por mais que se questione a existência de uma "Democracia Racial" no Brasil, é fato que a sociedade brasileira vivenciou um processo de miscigenação singular. Nesse sentido, elucida Lessa ${ }^{59}$ que "O Brasil não tem cor. Tem todo um mosaico de combina-

\footnotetext{
53 MANTOAN, Maria Tereza Eglér. Inclusão escolar: o que é? Por quê? Como fazer? São Paulo: Moderna, 2006. p. 82.

54 SARLET, Ingo Wolfgang. A eficácia dos direitos fundamentais. 7. ed. ver. atual. e ampl. Porto Alegre: Livraria do Advogado, 2007. p. 123.

55 SARLET, Ingo Wolfgang. A eficácia dos direitos fundamentais. 7. ed. ver. atual. e ampl. Porto Alegre: Livraria do Advogado, 2007. p. 123.

56 BRASIL. Supremo Tribunal Federal. Arguição de Descumprimento de Preceito Fundamental no 186. Voto do Min. Gilmar Mendes. Brasília, DF. Julgamento: 25 e 26/04/2012f, p. 25. Disponível em: http://www.stf.gov.br. Acesso em: 27 out. 2018.

57 A injúria racial está prevista no artigo 140 , parágrafo $3^{\circ}$, do Código Penal, que estabelece a pena de reclusão de um a três anos e multa, além da pena correspondente à violência, para quem cometê-la. De acordo com o dispositivo, injuriar seria ofender a dignidade ou o decoro utilizando elementos de raça, cor, etnia, religião, origem ou condição de pessoa idosa ou portadora de deficiência. Já o crime de racismo, previsto na Lei n. 7.716/1989, implica conduta discriminatória dirigida a determinado grupo ou coletividade e, geralmente, refere-se a crimes mais amplos. Nesses casos, cabe ao Ministério Público a legitimidade para processar o ofensor. A lei enquadra uma série de situações como crime de racismo, por exemplo,recusar ou impedir acesso a estabelecimento comercial, impedir o acesso às entradas sociais em edifícios públicos ou residenciais e elevadores ou às escadas de acesso, negar ou obstar emprego em empresa privada, entre outros. CONSELHO NACIONAL DE JUSTIÇA. Conheça a diferença entre racismo e injúria racial, 08 jun. 2015. Disponível em: http://www.cnj.jus.br/noticias/cnj/79571-conheca-a-diferenca-entre-racismo-e-injuria-racial. Acesso em: 02 fev. 2019.

58 BRASIL. [Constituição (1988) ]. Constituição da República Federativa do Brasil. Brasília, DF: Senado Federal, 1988.

59 LESSA, Carlos. "O Brasil não é bicolor", In: FRY, Peter e outros (org.) Divisões Perigosas: políticas raciais no Brasil contemporâneo. Rio de Janeiro: Civilização Brasileira, 2007. p. 123
} 
ções possíveis". Na Pesquisa Nacional por Amostras de Domicílio (PNAD), em 1976, os brasileiros se auto atribuíram 135 cores distintas.

Tal fato demonstra, cabalmente, a dificuldade dos brasileiros de identificarem a sua cor de pele. Para Oliveira ${ }^{60}$, "ser negro é, essencialmente, um posicionamento político, em que se assume a identidade racial negra. Identidade racial-étnica é o sentimento de pertencimento a um grupo racial ou étnico, decorrente de construção social, cultural e política".

De acordo com Lewandowski ${ }^{61}$, relator da ação, a decisão não contrariou o art. 208, inciso V, da Constituição Federal de 1988, que prevê que os níveis mais elevados de ensino, pesquisa e criação artística serão alcançados segundo a capacidade de cada um, uma vez que "o constituinte teria buscado temperar o rigor da aferição do mérito dos candidatos que pretendessem acesso às universidades com o Princípio da Igualdade Material".

Dessa forma, entende-se que as aptidões dos candidatos devem ser aferidas em conjunto, estando de um lado o seu conhecimento técnico e sua criatividade intelectual ou artística e do outro a sua capacidade potencial que ostentam para intervir nos problemas sociais. Outro ponto importante que pode ser observado na utilização do sistema de cotas nas universidades é o convívio de diversos grupos sociais no mesmo ambiente de ensino, sendo bastante enriquecedora a troca de experiências e pensamentos. Apenas com a eliminação das desigualdades sociais será possível verificar um Brasil desenvolvido, não apenas em relação a aspecto social como, também, econômico ${ }^{62}$.

Entretanto, é necessário reforçar a necessidade da natureza transitória da ação afirmativa para que essa medida seja considerada legítima, tendo em vista que a igualdade entre negros e brancos não resulta de uma desvalia natural ou genética de caráter permanente, mas de situações históricas. Isso não quer dizer que não haja problemas "raciais" no Brasil. O preconceito está em toda parte. Como dizia Bobbio, "não existe preconceito pior do que o acreditar não ter preconceitos". Em vista disso, na medida em que essa desigualdade for sendo corrigida, não haverá mais razão da permanência do sistema de cotas, uma vez que seu objetivo já terá sido alcançado ${ }^{63}$.

Segundo o Min. Lewandowski ${ }^{64}$, caso as políticas de ação afirmativa persistam ao final do quadro de exclusão social ao qual originou, essas medidas passarão ao ser benesses permanentes concedidas em prol de determinado grupo de pessoas, em prejuízo da coletividade como um todo, gerando uma situação incompatível com o Estado Democrático ao qual se firma a Constituição Federal de 1988.

Nesse sentido, o Estado brasileiro, pela primeira vez na sua história, trata desigualdades raciais como uma questão racional específica, relevante, importante para a nação do ponto de vista social e econômico. Os conceitos de desenvolvimento, historicamente excludente, pensados com referências na conjuntura e desconsiderando as desigualdades estruturais, estão sendo reformulados no Brasil para incluir os grupos humanos que têm sido, no processo histórico, imobilizados na parte inferior da pirâmide social ${ }^{65}$.

Nota-se, portanto, que a adoção de sistemas de cotas, com base nas cotas étnico racial nas universidades é uma política de ação afirmativa necessária para a eliminação da discriminação racial existente no país como

\footnotetext{
${ }^{60}$ OLIVEIRA, Fátima. Ser negro no Brasil: alcances e limites, Revista de Estudos Avançados, São Paulo, v. 18, n. 50, jan./abr. 2004.

${ }^{61}$ BRASIL. Supremo Tribunal Federal. Arguição de Descumprimento de Preceito Fundamental n ${ }^{\circ} 186$. Voto do Relator: Ministro Ricardo Lewandowski. Brasília-DF. Julgamento: 25 e 26/04/2012ª . Disponível em: http://www.stf.gov.br. Acesso em: 27 out. 2018.

62 BRASIL. Supremo Tribunal Federal. Arguição de Descumprimento de Preceito Fundamental n ${ }^{\circ} 186$. Voto do Relator: Ministro Ricardo Lewandowski. Brasília-DF. Julgamento: 25 e 26/04/2012a . Disponível em: http://www.stf.gov.br. Acesso em: 27 out. 2018. p. 10.

63 BRASIL. Supremo Tribunal Federal. Arguição de Descumprimento de Preceito Fundamental n 186 . Voto do Relator: Ministro Ricardo Lewandowski. Brasília-DF. Julgamento: 25 e 26/04/2012a. Disponível em: http://www.stf.gov.br. Acesso em: 27 out. 2018. p. 10.

64 BRASIL. Supremo Tribunal Federal. Arguição de Descumprimento de Preceito Fundamental n ${ }^{\circ} 186$. Voto do Relator: Ministro Ricardo Lewandowski. Brasília-DF. Julgamento: 25 e 26/04/2012a . Disponível em: http://www.stf.gov.br. Acesso em: 27 out. 2018. p. 15.

65 BRASIL. Supremo Tribunal Federal. Arguição de Descumprimento de Preceito Fundamental n ${ }^{\circ} 186$. Voto do Relator: Ministro Ricardo Lewandowski. Brasília-DF. Julgamento: 25 e 26/04/2012a , p. 22. Disponível em: http://www.stf.gov.br. Acesso em: 27 out. 2018.
} 
forma de concretização do direito fundamental à igualdade, desde que perdure somente enquanto não seja exterminada a desigualdade ${ }^{66}$.

Nesse sentido, Sarlet ${ }^{67}$ sustenta que:

Aplicam-se, portanto, as mesmas diretrizes incidentes nos demais casos de eficácia dos direitos fundamentais nas relações jurídico-privadas, dependendo o grau de proteção da maior ou menor intensidade da ameaça à liberdade por parte dos que exercem o poder social, viabiliza, em caso de manifesta insuficiência ou mesmo omissão do legislador, a realização do dever de proteção pelos órgãos jurisdicionais, inclusive colmatando eventuais lacunas com base nas próprias normas de direitos fundamentais. [...] restando virtualmente inconteste a importância dos assim denominados poderes privados para o problema da vinculação dos particulares e embora controverso - também aqui - o modo e intensidade da vinculação, importa que se deixe consignada a salutar tendência no sentido de se admitir, cada vez mais, que os direitos fundamentais atuam, em verdade, como forma de defesa contra toda e qualquer opressão, auxiliando, de tal sorte, na superação do fenômeno que oportunamente foi designado de " neofeudalismo social", característico da moderna sociedade industrial tecnológica.

Dessa forma, para que a consolidação do Estado democrático de direito seja realmente efetivada, é necessário a concretização dos direitos fundamentais em toda sua abrangência, principalmente no que diz respeito aos direitos de liberdade, igualdade, dignidade da pessoa humana, e por consequência, a efetivação da democracia por meio da participação cidadã ${ }^{68}$.

A matéria atrai, ainda, a análise sobre a noção de reserva da administração e a de reserva de lei. Sabe-se que a reserva de lei, em sua acepção de "reserva de Parlamento", exige que certos temas, dada a sua relevância, sejam objeto de deliberação democrática, num ambiente de publicidade e discussão próprio das casas legislativas. Busca-se assegurar, com isso, a legitimidade democrática para a regulação normativa de assuntos que sensibilizem a comunidade ${ }^{69}$. A reserva de lei tem especial significado na conformação e na restrição dos direitos fundamentais. A Constituição autoriza a intervenção legislativa no âmbito de proteção dos direitos e garantias fundamentais. O conteúdo da autorização para intervenção legislativa e a sua formulação podem assumir significado transcendental para a maior ou menor efetividade das garantias fundamentais ${ }^{70}$.

Nos últimos anos, no que diz respeito ao tratamento da temática racial, têm ocorrido no Brasil mudanças significativas que estão produzindo um intenso debate na sociedade em geral, e no meio acadêmico em particular, acerca da pertinência da adoção de políticas de ações afirmativas. Embora o debate tenha se concentrado fortemente no sistema de cotas para as universidades públicas, a atuação do governo envolve ações afirmativas em outras áreas com características e escopo diferenciados ${ }^{71}$.

Ainda no enfoque das ações afirmativas como instrumentos para efetivação do direito fundamental à educação o Supremo Tribunal Federal, ainda, em 09 de maio de 2012, em maioria de votos confirmou a constitucionalidade do sistema de cotas adotado pela Universidade Federal do Rio Grande do Sul (UFGRS), a partir da decisão no julgamento do Recurso Extraordinário (RE 597.285/RS), com repercussão geral, em que um estudante questionava os critérios adotados pela UFRGS para a reserva de vagas.

No Recurso Extraordinário, a universidade argumentou que o programa de cotas raciais deve ser visto como uma tentativa de dar à população negra e àquela de baixa renda outra autoestima, marcada não apenas no esporte, na música ou nas artes, mas também por referências nas profissões liberais, nas empresas, nos

${ }_{66}$ SARLET, Ingo Wolfgang. A eficácia dos direitos fundamentais. 7. ed. ver. atual. e ampl. Porto Alegre: Livraria do Advogado, 2007. p. 89.

67 SARLET, Ingo Wolfgang. A eficácia dos direitos fundamentais. 7. ed. ver. atual. e ampl. Porto Alegre: Livraria do Advogado, 2007. p. 132-133.

68 SILVA, Juliana Gomes. Direitos humanos, constituição e políticas públicas. Curitiba: Multideia, 2015. v. 2 p. 300.

69 BRASIL. Supremo Tribunal Federal. Arguição de Descumprimento de Preceito Fundamental n ${ }^{\circ} 186$. Voto do Relator: Ministro Ricardo Lewandowski. Brasília-DF. Julgamento: 25 e 26/04/2012a , p. 25. Disponível em: http://www.stf.gov.br. Acesso em: 27 out. 2018.

70 BRASIL. Supremo Tribunal Federal. Arguição de Descumprimento de Preceito Fundamental $n^{0} 186$. Voto do Relator: Ministro Ricardo Lewandowski. Brasilia-DF. Julgamento: 25 e 26/04/2012a , p. 25. Disponível em: http://www.stf.gov.br. Acesso em: 27 out. 2018. p. 26.

71 BRASIL. Supremo Tribunal Federal. Arguição de Descumprimento de Preceito Fundamental $n^{\circ} 186$. Voto do Relator: Ministro Ricardo Lewandowski. Brasília-DF. Julgamento: 25 e 26/04/2012ª p. 25. Disponível em: http://www.stf.gov.br. Acesso em: 27 out. 2018. p. 26. 
cargos públicos de comando, enfim, nos diversos espaços sociais. Para isso, transitoriamente (e o programa de cotas é e deve ser transitório), a universidade deve acelerar a formação de lideranças negras para um novo ambiente, marcado pela diversidade nos mais diversos segmentos sociais ${ }^{72}$.

Quando se fala em ações afirmativas, não se pode esquecer que, por meio, desse instituto, se está, acima de tudo, ofertando inclusão social de parte da sociedade que não pôde beneficiar-se do ensino básico que lhe promovesse a igualdade de condições para disputa de vagas em universidade pública ${ }^{73}$. Nessa órbita, a aplicação do Princípio da Igualdade deve primar pelo tratamento desigual entre os desiguais, na medida de suas desigualdades. Nesse sentido, destaca-se a passagem de Rui Barbosa ${ }^{74}$ :

A regra da igualdade não consiste senão em quinhoar desigualdade aos desiguais, na medida em que se desigualam. Nesta desigualdade social, proporcionada à desigualdade natural, é que se acha a verdadeira lei da igualdade. Tratar com desigualdade a iguais, ou a desiguais com igualdade, seria desigualdade flagrante, e não igualdade real.

Por fim, na mesma sequência, é possível prescrever acerca de uma conquista no âmbito do exercício de funções administrativas por parte do povo negro, especialmente a partir do seu ingresso no serviço público. O plenário do Supremo Tribunal Federal, em sessão realizada no dia 08 de junho de 2017, concluiu o julgamento da Ação Declaratória de Constitucionalidade (ADC) 41. Tal ação teve como pressuposto discutir sobre a Lei de Cotas no Serviço Público Federal, uma vez que a Lei no 12. 990/2014 reserva 20\% das vagas oferecidas em concursos públicos para provimento de cargos efetivos e empregos públicos no âmbito da Administração Pública Direta e Indireta, no âmbito dos três poderes.

Nesse contexto, decidiu, de forma unânime, o plenário do STF pela constitucionalidade da norma. O ministro Luis Roberto Barroso votou, por exemplo, pela constitucionalidade da norma, pois considerou que “a lei é motivada por um dever de reparação história decorrente da escravidão e de um racismo estrutural presente na sociedade brasileira ${ }^{75}$ ". Já a ministra Carmen Lúcia salientou que "o preconceito muitas vezes — contra negros ou contra mulheres - é insidioso e existe de forma acobertada, e outras vezes é traduzido em brincadeiras, que nada mais são do que verdadeiras injúrias, que indignam ${ }^{76 "}$.

Sendo assim, é matéria de extrema sensibilidade jurídica e social a implementação de ações afirmativas, bem como cotas, nas mais diversas formas e medidas, como instrumentos potenciais que auxiliam na efetivação dos princípios constitucionais amplamente cristalizados na Constituição Federal de 1988, a fim de possibilitar que camadas historicamente sufocadas e oprimidas, como o povo negro, possam se realocar no âmbito da sociedade contemporânea, tendo a oportunidade de ascender social, cultural e economicamente. Desse modo, imprescindível que o Estado estabeleça medidas que proporcionem a inclusão efetiva dessas camadas sociais em direitos assegurados constitucionalmente tais como saúde, educação, moradia, dentre outras prerrogativas extremamente relevantes.

\footnotetext{
72 AYUB, Carlos Eduardo Garrastazu. Ações Afirmativas como Direito Fundamental à Educação - (Comentário sobre Acórdão Proferido pelo Plenário do Supremo Tribunal Federal - Recurso Extraordinário no 597.285/RS). Revista da Ajuris, v. 42, n. 137, mar. 2015. p. 554.

73 AYUB, Carlos Eduardo Garrastazu. Ações Afirmativas como Direito Fundamental à Educação - (Comentário sobre Acórdão Proferido pelo Plenário do Supremo Tribunal Federal - Recurso Extraordinário no 597.285/RS). Revista da Ajuris, v. 42, n. 137, mar. 2015. p. 556.

74 BARBOSA, Rui. Oração aos Moços. Martin Claret: São Paulo, 2003. p. 19.

75 BRASIL. Supremo Tribunal Federal. Ação Declaratória de Constitucionalidade n ${ }^{\circ} 41$. Ministro relator: Min Roberto Barroso. Brasília, DF. Julgamento: 08/06/2017. Disponível em: http://portal.stf.jus.br/processos/detalhe.asp?incidente=4917166. Acesso em: 02 mar. 2019.

76 BRASIL. Supremo Tribunal Federal. Ação Declaratória de Constitucionalidade n 41. Ministro relator: Min Roberto Barroso. Brasília, DF. Julgamento: 08/06/2017. Disponível em: http://portal.stf.jus.br/processos/detalhe.asp?incidente=4917166. Acesso em: 02 mar. 2019.
} 


\section{Considerações finais}

Tratar da discriminação racial no Brasil e efetivamente das práticas muitas vezes de racismo, que são amplamente verificadas no país, não é algo atual, uma vez que o tema vem sendo largamente explorado em diversos meios, como o acadêmico, político e também a seara jurídica. Todavia, o trabalho aqui desenvolvido permeou tal assunto sob a ótica da ascensão do povo negro, trabalhando, ainda, a perspectiva de efetivação dos seus direitos e garantias a partir do respeito e da necessidade de aplicação dos princípios constitucionais, especialmente o da Dignidade da Pessoa Humana e da Igualdade em sua modalidade material. Ante ao todo demonstrado, fica perceptível, imediatamente, que a discriminação racial continua existindo no Brasil, muito embora a sociedade tente disfarçar seus preconceitos. Nesse seguimento, o Estado reconheceu a necessidade de garantir igualdade de condições entre negros e brancos, isonomia antes não prevista e não desenvolvida.

Sendo assim, o artigo preocupou-se em delinear tais perspectivas ancorado em três eixos temáticos, sendo o primeiro deslocou um olhar acerca do povo negro dentro do paradigma histórico, cultural e jurídico, potencializando a observância de como o povo negro vinha sendo tratado, sobretudo nessa ampla e irrestrita dinâmica de discriminação racial. De outra banda, o segundo eixo tratou de promover a visualização do povo negro no aspecto contemporâneo, quer dizer acerca das possibilidades de ascensão dentro da morfologia social implementada nos dias de hoje. Por fim, a última seção destacou a necessidade de aplicação dos princípios constitucionais, os quais amplamente respeitados têm o condão de promover uma cidadania efetivamente inclusiva e, dentro desse contexto, destacou-se como ferramenta, a ADPF n ${ }^{\circ} 186$.

A Constituição Federal brasileira de 1988 trouxe consigo muitos dispositivos em prol da igualdade, da não discriminação, da preservação dos direitos humanos. Logo, os direitos fundamentais são inerentes ao homem por sua condição de humano, sendo a dignidade da pessoa humana um princípio fundamental que não se pode renunciar ou vender. Para que se possam reverter as práticas racistas e segregacionárias implementadas no país, é preciso criar condições para reeducação da sociedade brasileira, nesse concernente que se entende como medida necessária a aplicação de ferramentas que potencializem essas trajetórias de inclusão, como as ações afirmativas que reverberam um caminho a ser seguido.

A discriminação racial fere os direitos humanos na medida em que exalta uns em detrimento de outros, nesse sentido, apesar dos avanços alcançados nos níveis de educação e rendimento da população brasileira, os negros são mais atingidos sobre o aspecto da taxa de analfabetismo. Nesse contexto, a discriminação racial é facilmente percebida e pode ser punida de imediato, todavia a sociedade tem caminhado para um outro tipo de discriminação racial, esta mascarada por normas e atitudes aparentemente inofensivas, que vem sendo reconhecida pelo judiciário, muito embora ainda que tímida a sua punição.

Reconhecer a existência de discriminação racial no Brasil é uma forma de organizar políticas em leis em favor da não discriminação. O Estatuto da Igualdade Racial é um importante instrumento na luta por igualdade, devendo ser conhecido, respeitado e implementado. Uma lei sozinha não é capaz de extirpar da sociedade um problema de gerações, já que a igualdade depende de um maior esclarecimento da população, pois a educação é a base de uma sociedade organizada e justa.

Assim, as ações do Poder Público não são capazes de, sozinhas, promover uma mudança na sociedade, no entanto, a legislação atual em prol da dignidade da pessoa humana e a igualdade, princípios constitucionais, abrem a visão da população com um novo olhar, de um modo geral mais positivo, abrangente, plural e inclusivo. Nota-se, portanto, que a adoção de sistemas de cotas, com base nas cotas étnico-raciais, dentro das universidades, é uma política de ação afirmativa necessária para a eliminação da discriminação racial existente no país como forma de concretização do direito fundamental à igualdade e também aplicação mais que devida do Princípio da Dignidade da Pessoa Humana, ambos baluartes da Constituição Federal de 1988 e do ordenamento jurídico pátrio, devendo ser amplamente respeitados e observados, porquanto potencializam as possibilidades de crescimento, desenvolvimento e da exponencial luta pela cidadania inclusiva. 


\section{Referências}

ALEXY, Robert. La naturaleza de la filosofía del derecho. Doxa, Barcelona, n. 26, 2003.

ARISTÓTELES. Política. 3. ed. Brasília: Universidade de Brasília, 1997.

ADORNO, Sergio. Discriminação Racial e Justiça Criminal em São Paulo. In: ADORNO, S. A criminalidade negra no banco dos réus: discriminação e desigualdade no acesso à justiça penal. Relatório de Pesquisa. Acordo NEV/USP-Geledés (Instituto da Mulher Negra). São Paulo: Núcleo de Estudos da Violência, 1994. Disponível em: https://edisciplinas.usp.br/pluginfile.php/203942/mod_resource/content/1/Adorno.pdf. Acesso em: 01 jun. 2018.

ASSIS, Marcelo Francisco de; AMORIM, Cleyde Rodrigues de. Racismo@online.com.br. Revista da ABPN, v.2, n. 4, mar. 2011 - jun. 2011. p. 131-149. Disponível em: http://www.abpnrevista.org.br/revista/index. php/revistaabpn1/article/view/325/299. Acesso em: 01 jun. 2018.

AYUB, Carlos Eduardo Garrastazu. Ações Afirmativas como Direito Fundamental à Educação - (Comentário sobre Acórdão Proferido pelo Plenário do Supremo Tribunal Federal - Recurso Extraordinário $n^{\circ}$ 597.285/RS). Revista da Ajuris, v. 42, n. 137, mar. 2015. Disponível em: http://www.ajuris.org.br/OJS2/ index.php/REVAJURIS/article/viewFile/373/307. Acesso em: 02 mar. 2019.

BASTIDE, Roger. Le rêve, la transe et la folie. 1972.

BARBOSA, Rui. Oração aos moços. Martin Claret: São Paulo, 2003.

BOBBIO, Norberto. Elogio da serenidade e outros escritos morais. São Paulo: Unesp, 2002.

BRASIL. [Constituição (1988)]. Constituição da República Federativa do Brasil. Brasília, DF: Senado Federal, 1988.

BRASIL. Lei no 12.288, de 20 de julho de 2010. Institui o estatuto da Igualdade Racial. Disponível em: http:// www.planalto.gov.br/ccivil_03/_Ato2007-2010/2010/Lei/L12288.htm. Acesso em: 01 mar. 2014.

BRASIL. Supremo Tribunal Federal. Arguição de Descumprimento de Preceito Fundamental n 186. Voto do Min. Gilmar Mendes. BrasíliaDF. Julgamento: 25 e 26/04/2012f. Disponível em: http://www.stf.gov.br. Acesso em: 27 out. 2018.

BRASIL. Supremo Tribunal Federal. Arguição de Descumprimento de Preceito Fundamental n ${ }^{\circ} 186$. Voto do Relator: Ministro Ricardo Lewandowski. Brasília-DF. Julgamento: 25 e 26/04/2012a. Disponível em: http:// www.stf.gov.br. Acesso em: 27 out. 2018.

BRASIL. Supremo Tribunal Federal. Ação Declaratória de Constitucionalidade $n^{\circ} 41$. Ministro relator: Min Roberto Barroso. Brasília, DF. Julgamento: 08/06/2017. Disponível em: http://portal.stf.jus.br/processos/ detalhe.asp?incidente=4917166. Acesso em: 02 mar. 2019.

CONSELHO NACIONAL DE JUSTIÇA. Conbeça a diferença entre racismo e injúria racial. 08 jun. 2015. Disponível em: http://www.cnj.jus.br/noticias/cnj/79571-conheca-a-diferenca-entre-racismo-e-injuria-racial. Acesso em: 27 out. 2018.

CZAJKOWSKI, Rainer. A crise do princípio da isonomia e a propriedade. In: RAMOS, Carmem Lucia Silveira. (coord.) Direito civil constitucional. Situações patrimoniais. Curitiba: Juruá, 2002. p. 187-205.

CANOTILHO, José Joaquim Gomes. Estudos sobre direitos fundamentais. Coimbra: Coimbra, 2004.

CANOTILHO, José Joaquim Gomes. Estado constitucional ecológico e democracia sustentada. In: GRAU, Eros Roberto; CUNHA, Sérgio Sérvulo da (coord.). Estudos de direito constitucional em homenagem a José Afonso da Silva. São Paulo: Malheiros, 2003 
DAMATTA, Roberto Augusto. Relativizando: uma introdução à Antropologia Social. Petrópolis, RJ: Vozes, 1984.

DAMATTA, Roberto Augusto. Carnavais, malandros e heróis: para uma sociologia do dilema brasileiro. Rio de Janeiro: Zahar, 1983.

DINIZ, Maria Helena. Curso de direito civil brasileiro: direito de família. 22. ed. São Paulo: Editora Saraiva, 2007. v. 5.

FERNANDES, Florestan. A integração do negro na sociedade de classes. 3. ed. São Paulo: Ática,1978.

FIGUEIREDO, Rita Vieira. Políticas de inclusão: escola gestão da aprendizagem na diversidade. In: ROSA, Dalva E.; SOUZA, Vanilton C. Gonçalves. Políticas organiz̧ativas e curriculares, educação inclusiva e formação de professores. Rio de Janeiro: DP\&A, 2002

FRISCHEISEN, Luiza Cristina Fonseca. Políticas públicas: a responsabilidade do administrador e o Ministério Público. São Paulo: Max Limonad, 2000.

GUIMARÃES, A. S. A. Racismo e anti-racismo no Brasil. São Paulo: Editora 34. 1999.

HASENBALG, Carlos. Discriminação e desigualdades raciais no Brasil. Belo Horizonte: UFMG; Rio de Janeiro: UPERJ, 2005.

HASENBALG, Carlos. Discriminação e desigualdades raciais no Brasil. Rio de Janeiro: UPERJ, 1988.

HOFBAUER, Andréas. Uma história de branqueamento ou o negro em questão. São Paulo: Unesp, 2005.

IANNI, Octavio. A dialética da globalização: teorias da globalização. Rio de Janeiro: Civilização Brasileira, 2004.

LESSA, Carlos. "O Brasil não é bicolor. In: FRY, Peter at al. (org.) Divisões perigosas: políticas raciais no Brasil contemporâneo. Rio de Janeiro: Civilização Brasileira, 2007.

LOPES, Eliana Marta Teixeira; GALVÃO, Ana Maria de Oliveira. História da Educação. 2. ed. Rio de Janeiro: DP\&A, 2005.

MANTOAN, Maria Tereza Eglér. Inclusão escolar: o que é? Por quê? Como fazer? São Paulo: Moderna, 2006.

MAIA, Marcos Chor. O Brasil no concerto das naçoes: a luta contra o racismo nos primórdios da UNESCO. 1998. Disponível em: http://www.scielo.br/scielo.php?script=sci_arttex\&pid. Acesso em: 01 jun. 2018.

MUGANGA, Kabengele. Algumas considerações sobre "raça", ação afirmativa e identidade negra no Brasil: fundamentos antropológicos. Revista USP, São Paulo, n. 68, p. 46-57, dez./fev. 2005-2006. Disponível em: file:///C:/Users/Bruno\%20Barros/Downloads/13482-16456-1-PB.pdf. Acesso em: 01 jun. 2018.

MUNANGA, Kabengele; GOMES, Nilma Lino. O negro no Brasil de hoje. São Paulo: Global, 2006.

OLIVEIRA, Fátima. Ser negro no Brasil: alcances e limites. Revista de Estudos Avançados, São Paulo, v. 18, n. 50, jan./abr. 2004.

PEREIRA, Caio Mário da Silva. Instituições de Direito Civil: direito de família. 16. ed. Rio de Janeiro: Editora Forense, 2005. v. 5.

RIGON, Angelo. Opinião e notícia. Disponível em: http://angelorigon.blogspot.com. Acesso em: 01 jun. 2018.

ROTHENBURG, Walter Claudios. Igualdade Material e Discriminação Positiva: o princípio da isonomia. Novos Estudos Jurídicos, v. 13, n. 2, 2008. Disponível em: https://siaiap32.univali.br/seer/index.php/nej/ article/view/1441. Acesso em: 07 out. 2018. 
SARLET, Ingo Wolfgang. A eficácia dos direitos fundamentais. 7. ed. ver. atual. e ampl. Porto Alegre: Livraria do Advogado, 2007.

SCHWARCZ, Lilia Moritz. Espetáculo da Miscigenação. Revista Estudos Avançados - USP, São Paulo, v. 8, n. 20, 1996. Disponível em: http://www.revistas.usp.br/eav/article/view/9652/11222. Acesso em: 01 jun. 2018.

SILVA, Juliana Gomes. Direitos humanos, constituição e políticas públicas. Curitiba: Multideia, 2015. v. 2.

SILVA, José Afonso. Curso de direito constitucional positivo. São Paulo: Malheiros, 2007.

SILVÉRIO, Valter Roberto. Raça e racismo na virada do milênio: os novos contornos da racialização. Tese (Doutorado em Sociologia) - Instituto de Filosofia e Ciências Humanas, Unicamp, Campinas, 1999.

STRECK, Lenio Luiz. Hermenêutica jurídica e $(m)$ crise: uma exploração hermenêutica da construção do Direito. 3. ed. Porto Alegre: Livraria do Advogado, 2002.

SUIAMA, Sergio Gardenghi. Identidades, diferenças. Boletim científico: Escola Superior do Ministério Público da União, Brasília, n. 2, p. 131-139, abr./jun. 2004.

TELLES, Edward. Racismo à brasileira: uma nova perspectiva sociológica. Rio de Janeiro: Relume Dumará, 2003.

WEDDERBURN, Carlos Moore. O racismo através da história: da antiguidade à modernidade. Copyright, 2007. 
Para publicar na revista Brasileira de Políticas Públicas, acesse o endereço eletrônico www.rbpp.uniceub.br

Observe as normas de publicação, para facilitar e agilizar o trabalho de edição. 